\title{
腔外科領域における腺リンパ腫の組織化学的検討
}

\author{
水野智之
}

\section{Histochemical investigation on adenolymphoma of oral area}

\author{
Tomoyuki Mizuno
}

\begin{abstract}
Investigation to elucidate the histochemical characteristics of adenolymphoma using normal salivary gland tissue as control, was carried out in immunohistochemical and mucushistochemical technique and the following findings were obtained: Localization of IgA, LF and SC in normal salivary gland tissue, siuggesting the defence of acinus unit, was the pertinent finding for the tissue defence mechanism which supported the presence of SC-transport mechanism and local immune system. Localization of Keratin in tumor tissue, suggesting the characteristic picture of densely staining epithelial basal cell skin to excretory duct, is the finding strongly implicating the execretory duct epithelial origin. The fall in positive rate associated with tumorigenesis of $\mathrm{LZ}$ implicated involvement of $\mathrm{LZ}$ in tumorigenesis. Acid mucus is dominant in productive mucus in normal salivary gland tissue and sialomucin is dominent in tumor tissue. Though the presence of glycosaminoglycan was confirmed by performing enzyme digestion method in normal salivary gland tissues, the evidence of glycosaminoglycan was not observed and imvolvement of myo-epithelial cell in tumorigenesis was negatively supported. In double stain of each antibody and mucus, the tendency toward dissociation was observed in all antibodies. Its when the cell with mucus producting potential was considered as the cell relatively well-differentiated in terms of function, the possibility, that CEA, SC, IgA, K, LF, L.Z were localized in the cells relatively poorly differentiated, was implicated. The localization of CEA in particular was suggested to be the possible index of cell dedifferentiation toward fetal tissue.
\end{abstract}

Key words: immunohistochemistry (免疫組織化学), mucushistochemistry (粘液組織化学), enzyme digestion method (酵素消化処理)

緒

言

唾液腺腫瘍は全身的見地からすれば比較的まれな腫瘍 に属するし，口腔外科領域の疾患としても重要なものの 一つである. そしてその組織学的病像は複雑多彩な様相 を呈するものが多く，かつ生物学的態度もまた一様でな いなどその組織発生由来や腫瘍特性についてこれまでの 多くの研究にもかかわらず，不明の点がな扰多く残さ れている.

\section{東京医科大学口腔外科学教室}

(主任：内田安信教授)

Department of Oral Surgery, Tokyo Medical

College (Chief: Prof. Yasunobu Uchida)

受付日：昭和63年11月 25 日
本研究は近年急速に発達, 普及した免疫組織化学的㭘 索手法と技術的に著しく向上, 多様化した粘液に関する 組織化学的技法を駆使することにより喠液腺腫㿇の中で も古くから特異な組織像を呈することによって知られて いる腺リンパ腫について腫瘍組織とその母組織と考えら れる原発部位に相当する正常唾液腺組織の組織学的観察 成績の対比によっていまた十分に解明されていない組織 発生由来および腫瘍特性に関して考究せんとしたもので ある。

\section{材料および方法}

\section{1. 険索材料}

東京医科大学病院病院病理部に集積された腺リンパ腫 17例および対照例20例, 計37例を対象とした。なお対照 
例は唾液腺疾患を有さない新鮮剖検例より採取した正常 唾液腺組織である。

\section{2. 研究方法}

検索に用いた組織はすべて10２0\%ホルマリンで固定 し，パラフィン包埋されたものである.

\section{1) 一般光顕的観察}

通法に従い厚さ $3 \mu$ の薄切片を作製後 Hematoxyline-Eosin 染色の他, 必要に応じて, Azan, Elsticavan Giesen 染色，鍍銀法などの常用特殊染色を施した。

2 ) 免疫組織化学的検索

ホルマリン固定パラフィン切片を用い, Hsu ら"によ って開発された ABC (Avidin-Biotin-Peroxidase Complex）法にて行った（図1）。すなわち，パラフィンプ ロックより薄切した厚さ $3 \mu$ の切片はキシロールで脱パ ラフィン後 $\mathrm{pH} 7.6$ の $0.01 \mathrm{M}$ 燐酸緩衝生食水（以下 PBS）に15分間浸漬し，さらに，内因性ペルオキシダー セ活性阻止のため $0.3 \%$ 過酸化水素水添加 $99 \%$ メタノ一 儿液中に 30 分間浸漬した，次に非特異的吸着反応を除去 する目的で10倍希釈の正常家鬼血清を用いて湿箱中で20 分間室温にて incubate させた後, 一次抗体を $4^{\circ} \mathrm{C}$ 湿箱 中で over night で反応させた。 反応終了後, PBS にて 5 分間 3 回洗浄し, Biotin 化二次抗体を30分湿箱中, 室 温で反応させ，再び PBS で 5 分間ずつ 3 回洗浄，次に Avidin-Biotin-Peroxidase Complex 溶液を室温湿箱中で 60 分間反応させた，反応終了後，流水中にて10分間水洗 ᄂ, $0.05 \%$ 3.3 Diaminobenzidine (SIGMA 社 USA) および $30 \%$ 過酸化水素水添加の $0.05 \mathrm{M}$ トリス緩衝液 （pH 7.6）で呈色反応を行った，すなわち，抗原部にぺ ルオキンダーゼが特異的に結合することにより diaminobenzidine が酸化され，茶褐色を呈することを確認し た，その後, 蒸留水洗で反応を停止させ Mayer の Hematoxylin で対比核染色，脱水，透徽を行い，60\% HSR 液（国際試薬社）製で封入した。 $\mathrm{ABC}$ 法はVector Laboratories 社 (USA) 製 Vectastain $\mathrm{ABC}$ kit (antirabbit Ig kit）を用いた。使用した一次抗体は DAKO 社 (Copenhagen Demmark) の poly-clonal antibody (rabbit) であり，その希釈倍率はおのおの次のとおりで ある. Carcinoembryonic antigen (以下 CEA) $1: 400$, Secretory Component (以下 SC) $1: 300$, Lactoferrin (以下 LF) $1: 300$, Lysozyme (以下 LZ) $1: 600$, Keratin (以下 K) $1: 200$, IgA (1:500) とした。な お各抗体の negative control はすべて正常家鬼血清を用 いた。

3 ) 粘液組織化学的娭索

ホルマリン固定パラフィンブロックより厚さ $3 \mu$ の薄 切片を作製し，Periodic-Acid-Shiff（以下 pH），PAS after Diastase degestion (以下 D-PAS), $\mathrm{pH} 2.5$ Alcian-Blue (以下 $\mathrm{AB}$ ), Colloidal-Iron (以下 $\mathrm{CI}$ ), High-Iron-Diamine（以下 HID）の各染色および PAS-

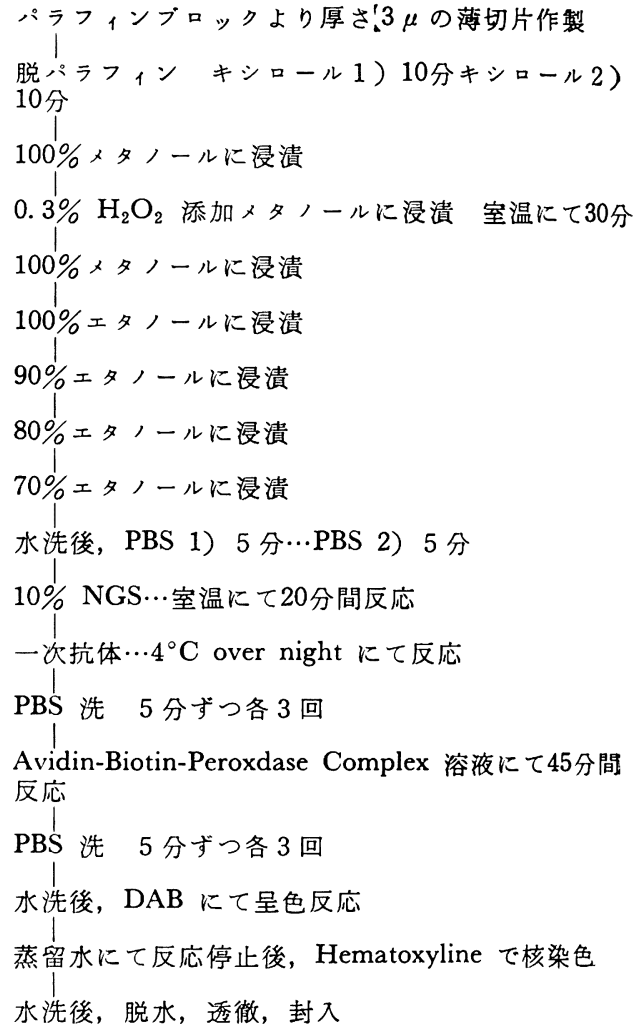

図 1 醅素抗体法 (ABC 法)

$\mathrm{AB}, \mathrm{HID}-\mathrm{AB}$ 重染色を施し，粘液物質の検索を行った (図 2 $)^{2,3)}$. 寸なわち PAS 反応，AB 染色を各々行い， さらに HID, $\mathrm{AB}$ 染色を行いこれらの組み合わせにより 中性ムチン，酸性ムチンに分類し，Spicer の方法"住準 して HID 染色を行い surfomucin を検出した，また消化 酵素処理を行らことにより上皮性細胞の中に含まれるム コ多糖群の同定を試みた。用いた酵素消化法はヒアルロ ン酸を特異的に消化する Streptomyces hyaluronidase 消 化法, ヒアルロン酸, コンドロイチン, コンドロイチン 硫酸 $\mathrm{A} ， \mathrm{C}$ を特異的に消化する Testicular-hyaluronidase 消化法である $(\text { 図 3 })^{5)}$.

i) Streptomyces hyaluronidase 消化法

ペラフィンブロックより薄切した厚さ $3 \mu$ の切片を通 法に従い脱パラフィンし，水中に浸漬する。ささらにこれ を Streptomyces hyaluronidase（生化学工業社製）を $100 \mathrm{TRU} / \mathrm{m} l$ の活性浱度で含む $0.1 \mathrm{M}$ リン酸塩緩衙液 $\left(\mathrm{pH} \mathrm{5.0)}\right.$ に 40 50 $0^{\circ} \mathrm{C}$ で 4 時間浸漬後水洗し, $\mathrm{pH} 2.5$ Alucian-Blue 染色を施した.

ii) Testicular hyaluronidase 消化法

脱パラフィン後の薄切片を Testicular hyaluronidase (Sigma Chem. Co 製)を0.1\%(W/V) の濃度で含む 


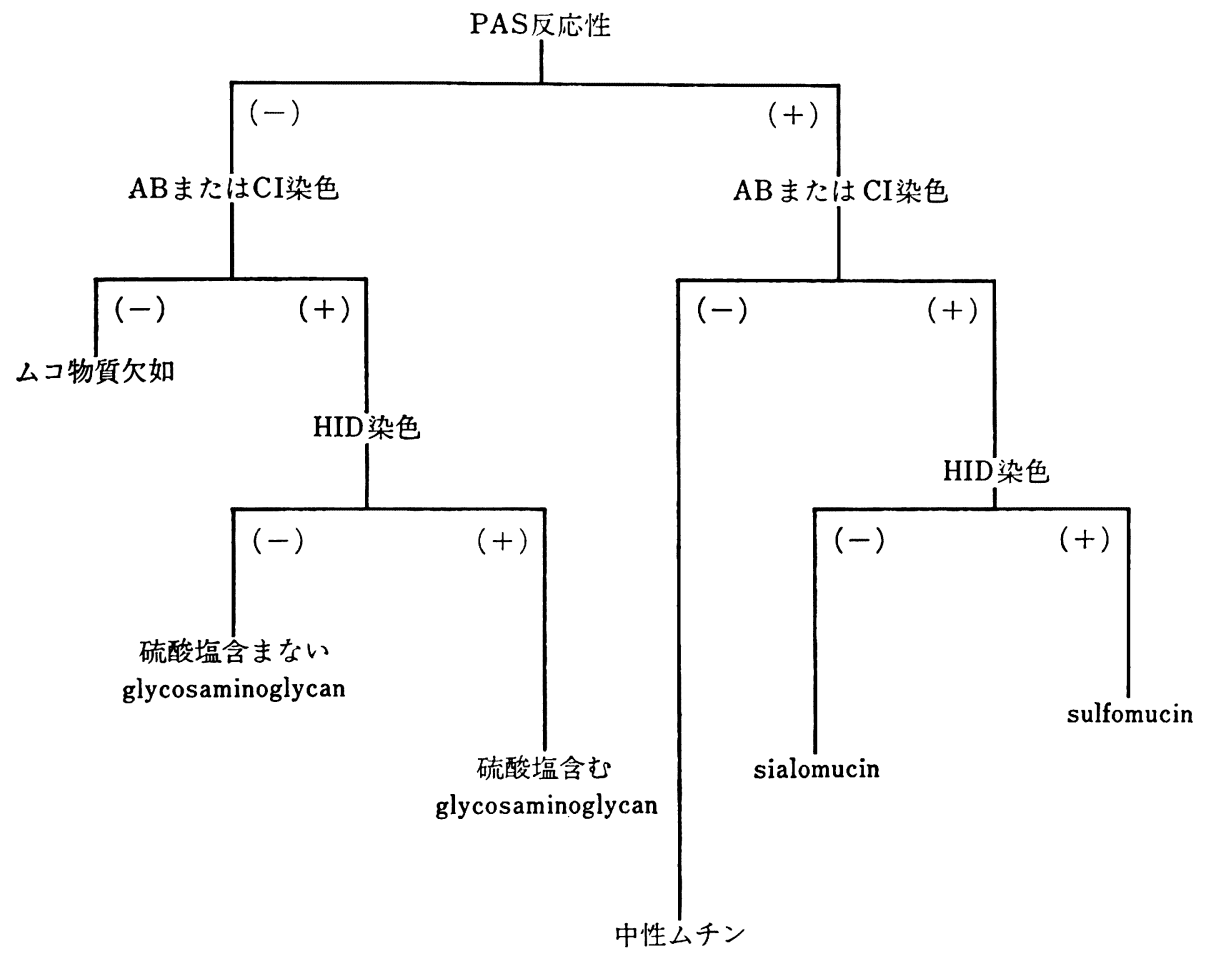

図2ム工物質の組織化学的解析

i) Streptomyces hyaluronidase 消化法 パラフィンブロックより厚さ $3 \mu$ の薄切片作製

通法に従い脱ハシラフィン‥*シロール1(10分) $\cdots$

キシロール2(10分)

水中に浸潰

Streptomyces hyaluronidase を $100 \mathrm{TRU} / \mathrm{ml}$ の活性窂度で含む $0.1 \mathrm{M}$ PBS (pH 5.0) に $40 \sim 50^{\circ} \mathrm{C}$ で 4 時間浸潰

水洗

pH 2.5 Alucian-Blue 染色

ii) Testicular hyaluronidase 消化法

ハラフィンブロックより厚さ $3 \mu$ の薄切片作製

脱パラフィン…*ロール 1(10分) …キシシロー

ル 2(10分)

Testicular hyaluronidase を $0.1 \%(\mathrm{~W} / \mathrm{V})$ の 活性濃度で含む0. $1 \mathrm{M}$ PBS (pH 5.5) に $37^{\circ} \mathrm{C}$ で 4 時間浸溃

水洗

pH 2. 5 Alcian-Blue 染色

図 3 酵素消化法
$0.1 \mathrm{M}$ リン酸塩緩衝液（pH 5.5）中に $37^{\circ} \mathrm{C} て ゙ 4$ 時間浸 漬後水洗し, $\mathrm{pH} 2.5$ Alcian-Blue 染色を施した。

\section{研 究 結 果}

\section{1. 症例の概要}

年齢は最高齢76歳, 最低齡 38 歳, 平均年齡 59 歳であ り，年代別では50代が 7 例と最も多かった．性別では男 性15例，女性 2 例であった。腫瘍の発生部位は，右側 6 例, 左側 11 例, 両側性に発生したものはみられなかっ た。これらはすべて外科的に全摘手術の行われたもので ある(表1，2）.

\section{2. 一般光顕的所見}

腫瘍は好酸性細顆粒状胞体を有する高円柱状のいわゆ る oncocytic な二層性または多列様配列を示す上皮細胞 成分よりなる実質と胈中心の形成を伴うリンパ組織成分 よりなる間質からなっており，これらは基底膜により隔 てられている．上皮成分のらち特に管腔に面する細胞は 高円柱状を呈し，基底膜に接する細胞は立方状を呈し， 規則正しく配列している。この腫瘍のリンパ組織成分に はリンパ球の他，組織球，マスト細胞，形質細胞などが 含まれる。 Seifert らにより ${ }^{6)}$, 本腫瘍はリンパ組織成分 と上皮組織成分の腫瘍内における割合による上皮組織成 
表 1 腺リンパ尰の性別および側性別発生率

\begin{tabular}{|c|c|c|c|c|c|c|c|c|c|c|c|c|}
\hline & \multicolumn{4}{|c|}{ 性 別 } & \multicolumn{6}{|c|}{ 側 別 } & & \\
\hline & \multicolumn{2}{|c|}{ 男 性 } & \multicolumn{2}{|c|}{ 女 性 } & \multicolumn{2}{|c|}{ 左 側 } & \multicolumn{2}{|c|}{ 右 㑡 } & \multicolumn{2}{|c|}{ 両側性 } & & \\
\hline & 例 & $\%$ & 例 & $\%$ & 例 & $\%$ & 例 & $\%$ & 例 & $\%$ & 合計 & $\%$ \\
\hline 腺リンパ腫 & 15 & 88.2 & 2 & 11.8 & 11 & 64.7 & 6 & 35.0 & 0 & 0 & 17 & 100 \\
\hline
\end{tabular}

表 2 腺リンハ腫の年齢階級別分布

\begin{tabular}{|c|c|c|c|c|c|c|c|c|c|c|c|c|}
\hline & \multicolumn{2}{|c|}{$0 \sim 20$ 歳 } & \multicolumn{2}{|c|}{$20 \sim 39$ 歳 } & \multicolumn{2}{|c|}{$40 \sim 59$ 蹁 } & \multicolumn{2}{|c|}{$60 \sim 79$ 藏 } & \multicolumn{2}{|c|}{ 80歳以上 } & \multicolumn{2}{|c|}{ 計 } \\
\hline & 例 & $\%$ & 例 & $\%$ & 例 & $\%$ & 例 & $\%$ & 例 & $\%$ & 例 & $\%$ \\
\hline 腺リンパ腫 & 0 & 0.0 & 1 & 5.9 & 7 & 41. 2 & 9 & 52.9 & 0 & 0 & 17 & 100 \\
\hline
\end{tabular}

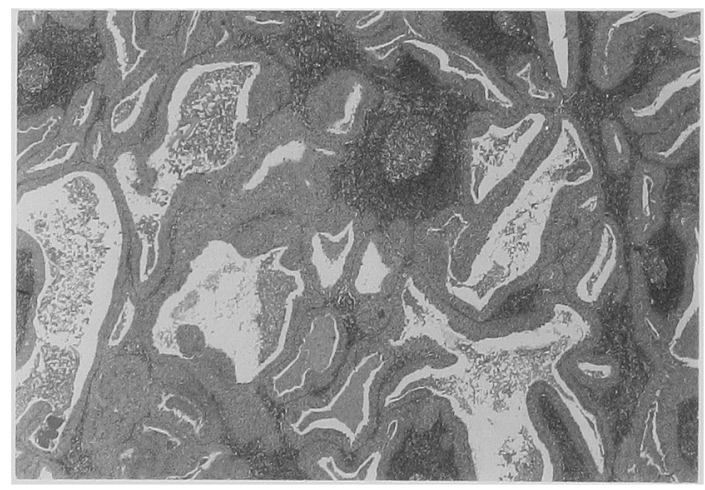

写真 1 腺リンパ董 (H-E 染色)

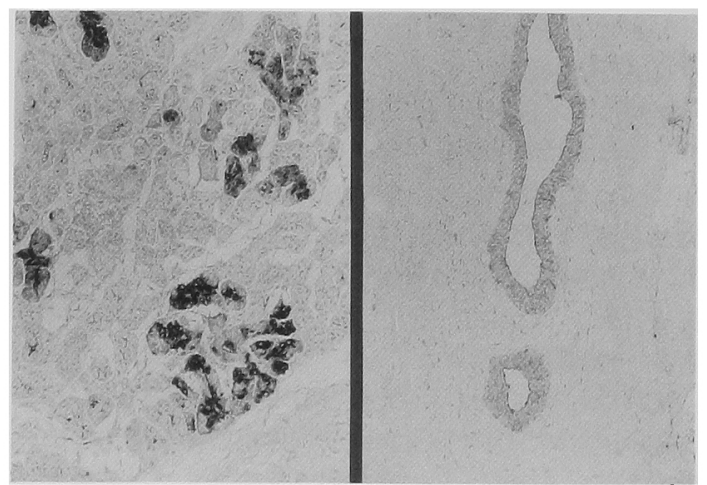

写真 2 正常亚液腺組織 (CEA ABC 法)

腺㞔細胞 渞管上皮細胞

分仵薙型，間質成分優警型，中間型の三型に分類されて いるが本换索例に扣いてて上皮組織成分俊勢型 3 例，間

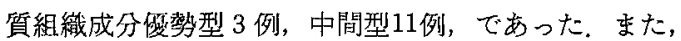
本検索症例では叚平上皮化生を示するのは見られなかっ

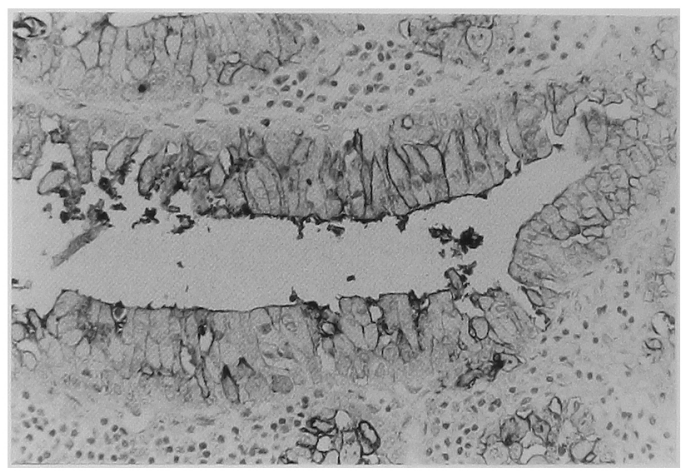

写真 3 腺リンパ稙（CEA ABC 法）

た（写真 1 ).

3. 免疫組織化学的検索所見

1) CEA について

正常唾液腺組織では，その染色性は腺房細胞および介 在部道管上皮細咆で高度陽性, 排泄部導管上皮細胞拈よ び腺条部導管上皮細胞で軽度陽性であった（写真 2).

尰瘍組織では㭘索例の $64.76 \%$ で管腔側上皮細胞に批い て中等度ないし高度陽性であった（写真了）。

2) Lactoferrin kついて

正常唾液腺組織では，腺房細胞和よび介在部導管上皮 細胞, 排泄部導管上皮細胞之もに高度陽性を示し（写真 4), 腫演組織では，管腔側上皮細胞において検索例の 41. 47\%で高度陌性であった（写真 5).

3) Secretory component Kついて

正常耤液腺組織中では，排泄部導管上皮細胞に高度陽 珄, 介在部導管上皮細狍，線条部導管上皮細胞口中等度

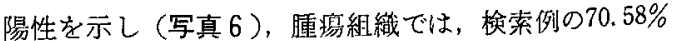
において管腔側上皮細胞で柽ないし中等度の陽性であっ た（写真 7 ). 


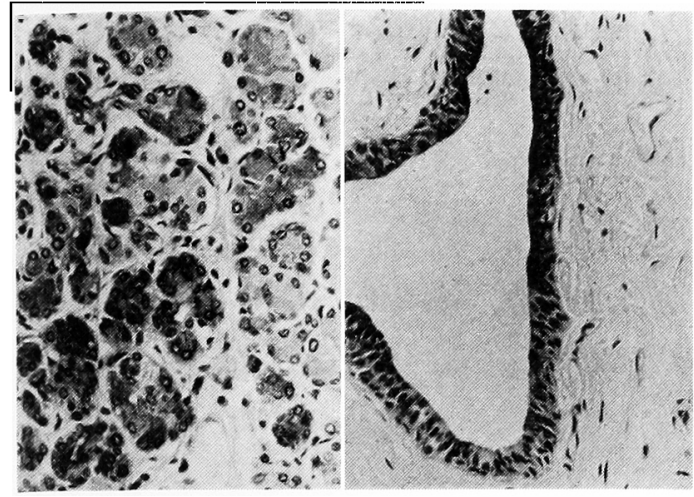

写真 4 正常咥液腺組織（LF ABC 法） 腺房紐胞 | 緮管上皮細胞

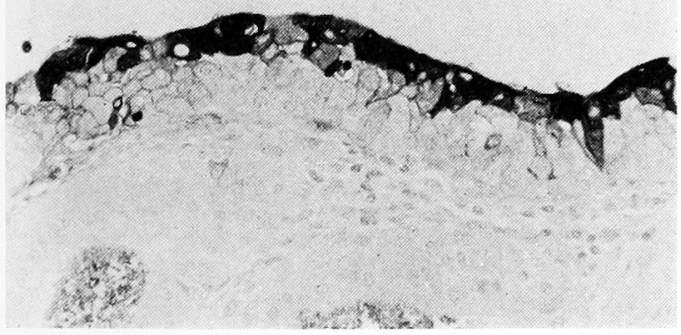

写真 5 腺リンパ腫 (LF ABC 法)

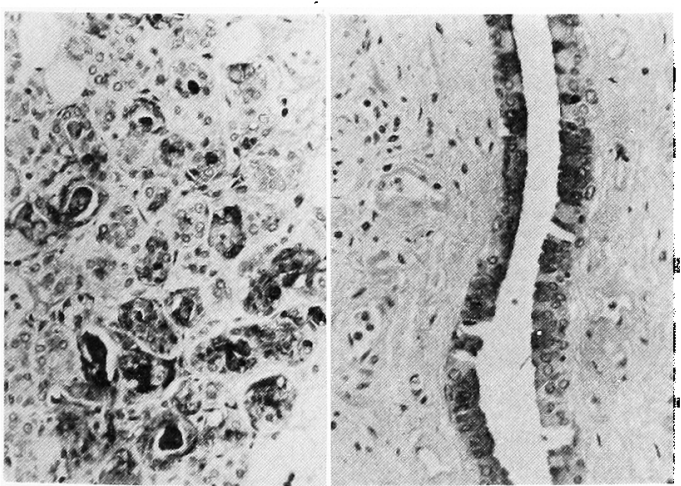

写真 6 正常吿液腺組織（SC ABC 法） 腺房細胞、尊管上皮細胞

4) Keratin について

正常唾液腺組織では，排泄部道管上皮細胞の基底側で 高度陽性，腺条部道管上皮細胞管腔側で中等度陽性を 示した（写真 8)，腫瘍組織では，すべての症例で管腔

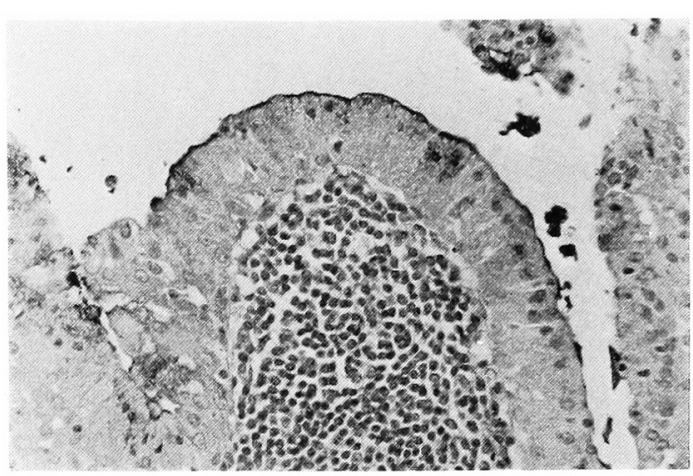

写真 7 腺リンパ腫 ( $\mathrm{SC} \mathrm{ABC}$ 法)

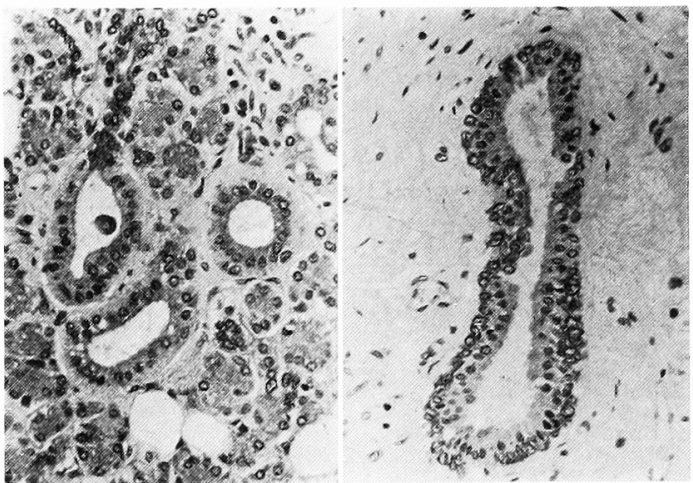

写真 8 正常唾液腺組織 ( $\mathrm{K}$ ABC 法) 腺房細胞（線状部）|導管上皮細胞

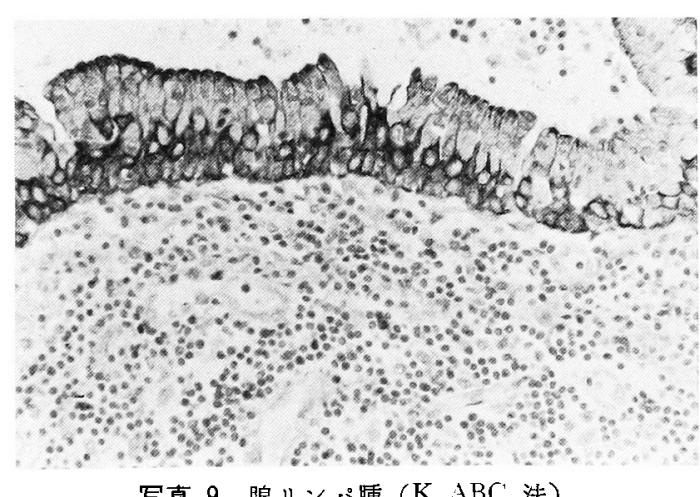

写真 9 腺リンパ盾 ( $\mathrm{K} A \mathrm{BC}$ 法)

側上皮細胞基底側を中心として高度の陽性であった（写 真 9 ).

4) $\operatorname{IgA}$ について

正常唾液腺組織では介在部導管上皮細胞, 線条部導管 


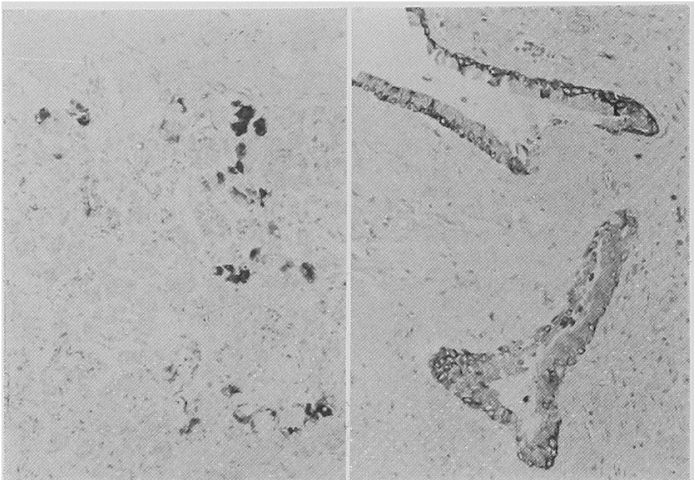

写真 10 正常唾液腺組織 ( $\mathrm{IgA} A B C$ 法) 腺房細胞|導管上皮細胞

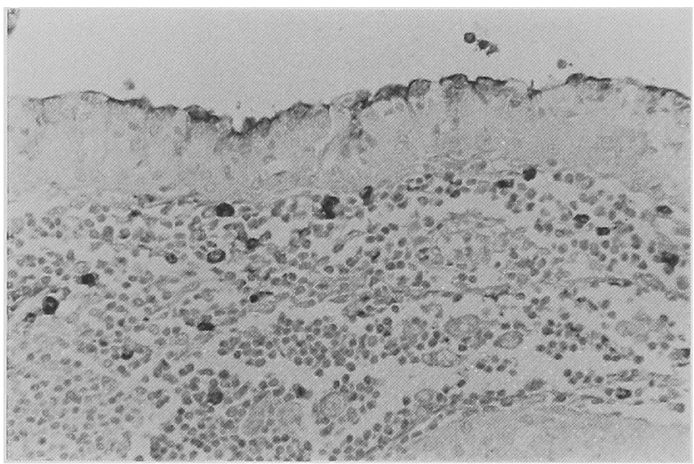

写真111 腺リンパ隀 ( $\operatorname{Ig} \mathrm{A} \mathrm{ABC}$ 法)

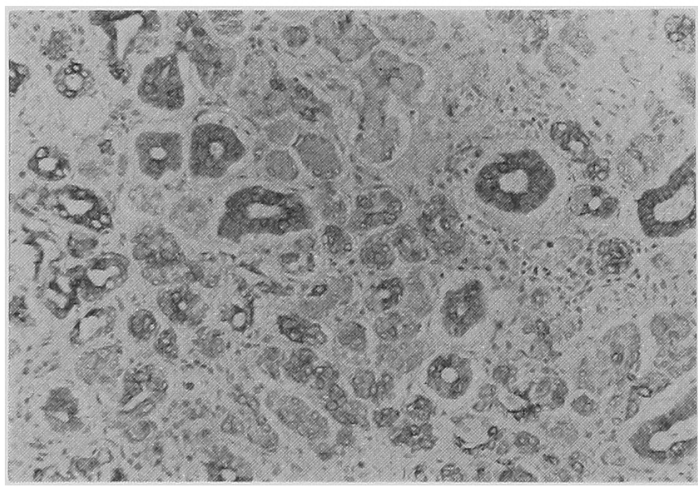

写真 12 正常哂液腺組織（LZ $\mathrm{ABC}$ 法）

上皮細胞で中等度の陽性を示し，排泄部導管上皮細胞で 中等度ないし高度の陽性を示して括り（写真 10），腺房 細胞では，軽度陽珄または陰性であった，腫瘍組織で は，検索例の $70.58 \%$ で管腔側上皮細胞に軽度ないし中 等度の陽性を示するのがあった（写真11）。

5) Lysozyme について

正常唾液腺組織では，介在部導管上皮細胞，線条部導
表 3 正常唾液腺組織に打ける各抗原の局在

1. Carcino-embryonic

antigen: 腺房稩胞（漿液細胞）(H) 介在部導管上皮稩胞 $(H)$ 線状部導管上皮細胞 $(+)$ 排泄部道管上皮細胞 $(+)$

2. Keratin: 腺房細胞（漿液細胞）(H) 排泄部導管上皮細胞 $(+)$

線状部導管上皮稩胞 (十)

3. Secretory Component: 腺房絀胞 (漿液細胞) (H) 排泄部導管上皮細胞 (十) 線状部導管上皮細胞 $(+)$ 介在部導管上皮細胞 $(+)$

4. Lactoferrin: 腺房細胞（漿液細胞）(H) 介在部導管上皮細胞 (H) 排泄部導管上皮細胞( (十)

5. IgA：介在部導管上皮細胞 (十) 線状部導管上皮稩胞 $(+)$

6. Lysozyme: 介在部導管上皮細胞 $(+)$ 線状部導管上皮細胞 $(+)$ 腺房稩胞 (墏液細胞) $(+)$

表 4 腺りンパ聥に括ける各抗原の局在

1. Carcino-embryonic antigen：管腔側上皮稩胞 $(+\sim H)$ 稩胞膜

2. Secretory component: 管腔側上皮紐胞 $( \pm \sim+)$

3. Keratin：管腔側上皮細胞

（基底側細胞を中心に(十)

4. Lactoferrin: 管腔側上皮紐胞 $(+\sim H)$

5. IgA：管腔溉上皮細胞 $( \pm \sim+)$

6. Lysozyme：管腔㑡上皮細胞 (H)

管上皮細胞に強い抗原性を示し, 腺房細胞に中等度陽性 を示しており（写真 12），排泄部導管上皮細胞は陰性で あった，腫湟組織では，明らかな局在は示さなかった (表 $3 \sim 5$ ).

\section{4. 粘液組織化学的検索所見}

正常唾液腺組織では，胞体内に PAS 反応陽性の影粒 か゚みられ（写真 13，14），このうち PAS 反応陽性粘液 はジアスターセ処理を施してる完全には陰性化すること なく $\mathrm{AB}-\mathrm{PAS}$ 重染色で $\mathrm{AB}$ 陽性の酸性ムチン霓位を示 すものが16例， $80 \%$ (写真15), AB，PAS 共に同程度の 陽性を示すもの 4 例，20\%であり，PAS 陽性の中性么 チン㯪位を示すものは見られなかった。 さらに酸性粘液 は HID-AB 染色で sialomucin と sulfomucin 飞染め わけられるが正常唾液腺組織では sialomucin 優位を示 
表 5 腺リンハ腫の免疫組織化学的解析

\begin{tabular}{l|c|c|c|c|c|c|c|c|c|c|c|c|c|c|c|c|c|cc}
\hline \multicolumn{1}{c}{ 症例番号 } & 1 & 2 & 3 & 4 & 5 & 6 & 7 & 8 & 9 & 10 & 11 & 12 & 13 & 14 & 15 & 16 & 17 & total & $\%$ \\
\hline $\begin{array}{l}\text { Carcinoembryonic } \\
\text { antigen }\end{array}$ & + & + & + & \pm & + & + & \pm & + & + & + & + & \pm & \pm & \pm & + & \pm & + & $11 / 17$ & 64.6 \\
Keratin & + & + & + & + & + & + & + & + & + & + & + & + & + & + & + & + & + & $17 / 17$ & 100.0 \\
Secretory & - & \pm & + & + & + & + & + & + & + & - & - & + & + & + & + & + & \pm & $12 / 17$ & 70.58 \\
$\quad$ Component & & & & & & & & & & & & & & & & & & & \\
Lactoferrin & - & + & + & - & + & + & - & \pm & - & - & - & - & \pm & + & + & \pm & + & $7 / 17$ & 41.17 \\
IgA & + & \pm & + & + & + & + & + & + & + & + & \pm & + & \pm & + & \pm & - & + & $12 / 17$ & 70.58 \\
Lysozyme & - & - & - & - & - & - & - & - & - & - & - & - & - & - & - & - & - & $0 / 17$ & 0.00 \\
\hline
\end{tabular}

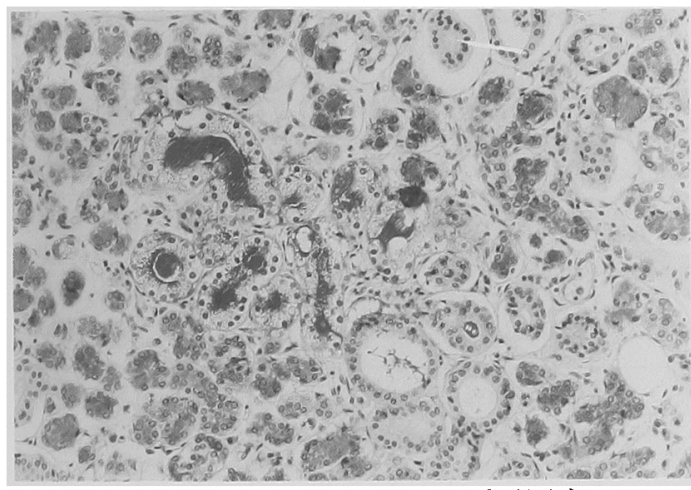

写真 13 正常唾液腺組織（PAS 染色）

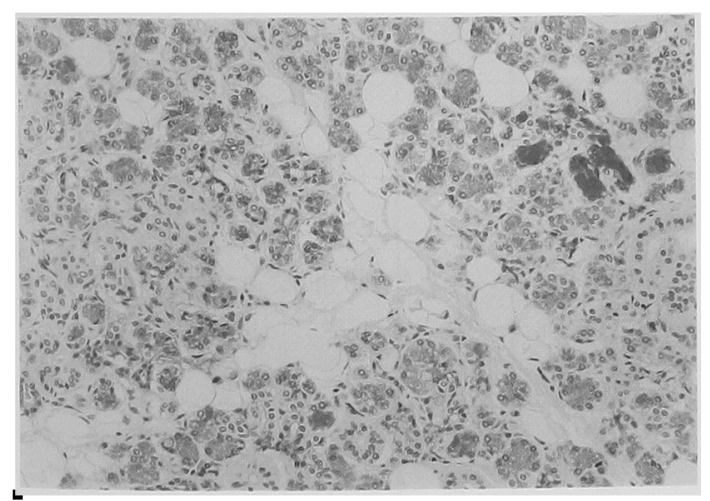

写真 14 正常哽液腺組織 (D-PAS 染色)

すもの14例, 70\% (写真16), sialomucin, sulfomucin と も，同程度の陽性所見を示すもの 6 例, 30\%, sulfomucin

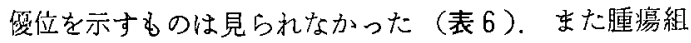
織では管腔を形成する二層性ないし多列梯模造を示す上 及細胞において裴層に配列するほとんどのものがPAS 反応浣性を示す線毛を被5 surface coat, cytoplasmic substance, intratubular substance 有しており(写真17， 表 7)、これらはジアスターゼ処理を行らことにより陰 性化する傾向示したことからP、. 反応物質の多くが

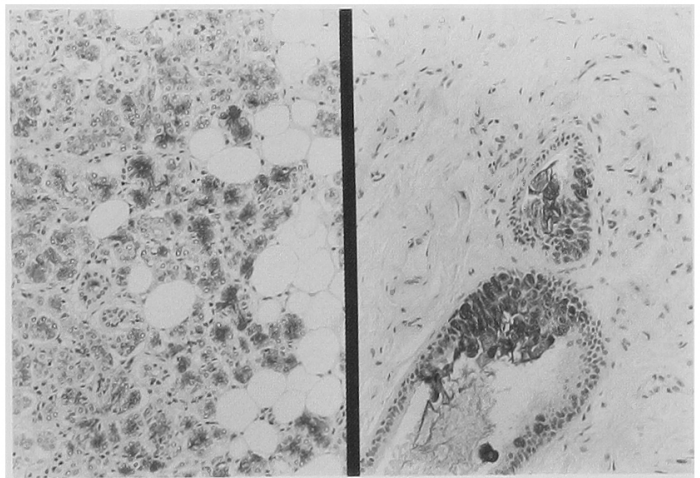

写真 15 正常㖶液腺組織（AB-PAS 染色） 腺房稩胞|導管上皮細胞

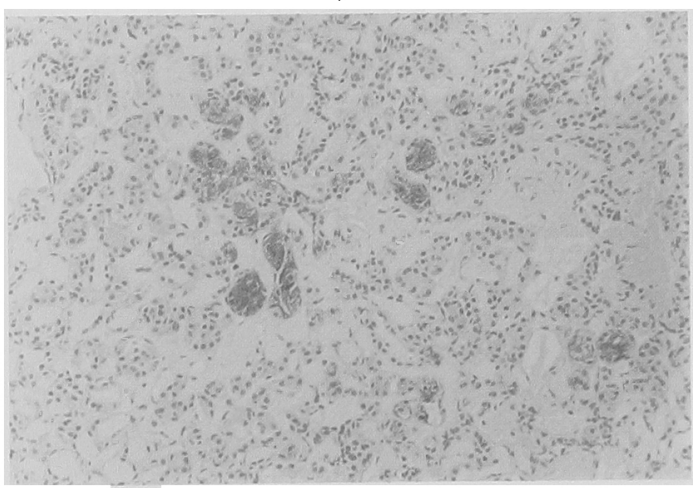

写真 16 正常殹液腺組織 (HID-AB 染色)

グリューゲンを主体としていることが考えられた（写真

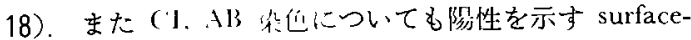
coat, cytoplasmic substance, intratubular substance 有寸る細胞が比䡆的小数ながら見ら机（写真19），HID$\mathrm{AB}$ 染色では $\mathrm{AB}$ 隄珄の sialomucin 传位の性格を示し ていた（写真 20，表 8)、またヒアルロン酸，コンドロ イチン硫酸などの glycosaminoglycan (以下 C.IG)に ついてはれらに streptomyces hyalronidase, testicular hyaluronidase の各消化試験を施しても陰性化すること 


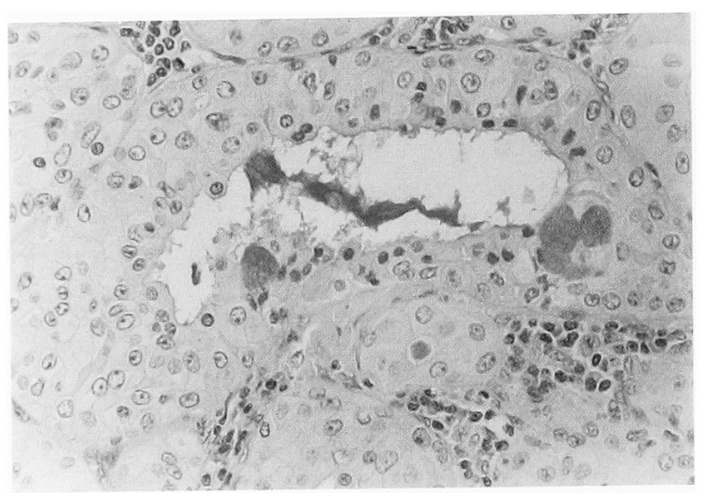

写真 17 腺リンハ腫 (PAS 染色)

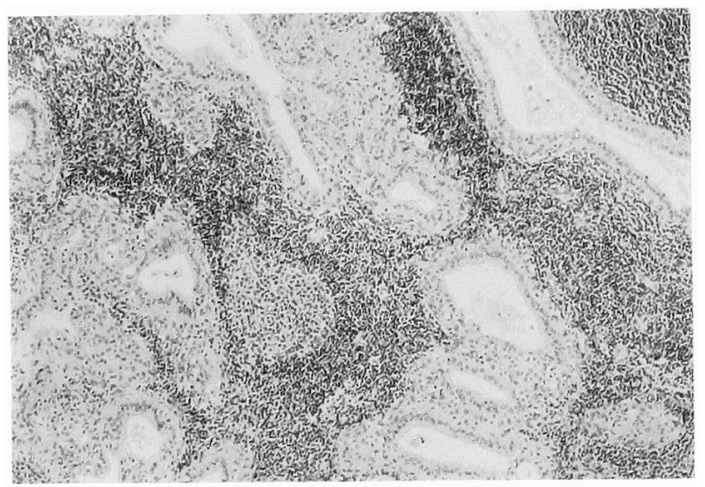

写真 18 腺リンパ腫 (D-PAS 染色)

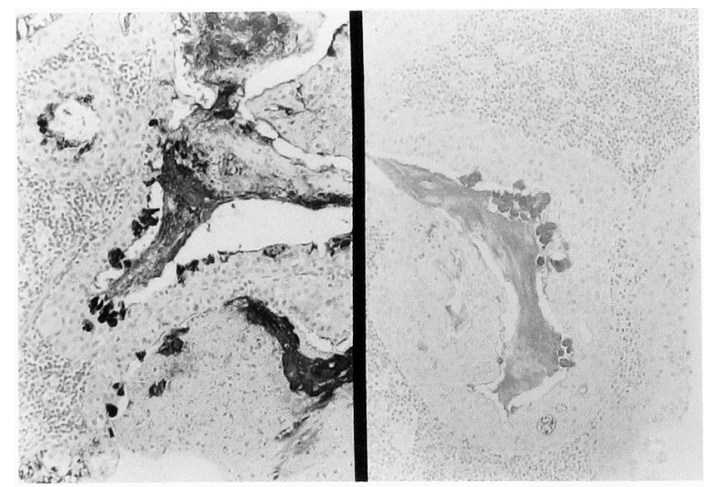

写真 19 腺リンパ腫（CI 染色， $\mathrm{AB}$ 染色）

なく上皮性粘液の性格を示していた。

なお，これらの各抗体と粘液の重染色についての観察 を行ったが腫痬組䄉においては管腔内以外にはそれぞれ の抗体と粘液との染色陽性部位の重複の見られるものは 少なかった。

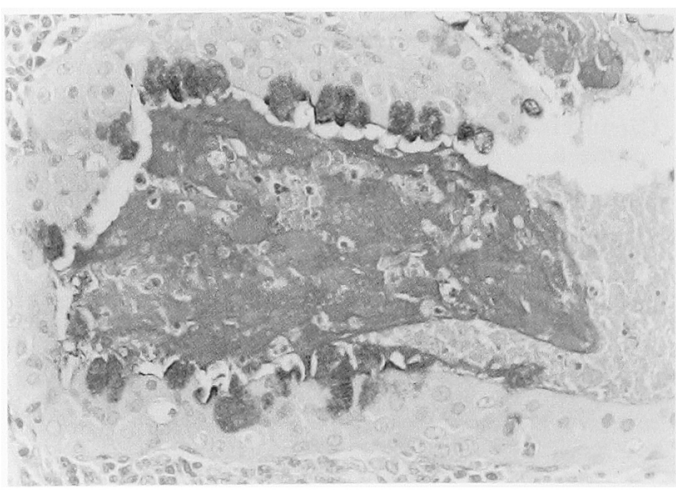

写真 20 腺 リンパ重 (HID-AB 染色)

表 6 正常唾液腺における粘液租成の検討

\begin{tabular}{|c|c|c|c|c|}
\hline 粘液染色 & \multicolumn{2}{|c|}{ AB-PAS } & \multicolumn{2}{|c|}{ HID-AB } \\
\hline 症例番号 & $\mathrm{AB}$ & PAS & $\mathrm{Si}$ & $\mathrm{Su}$ \\
\hline 1 & $H$ & + & $H$ & $H$ \\
\hline 2 & H & + & + & + \\
\hline 3 & $H$ & + & $H$ & H \\
\hline 4 & H & H & + & - \\
\hline 5 & H & + & $H$ & - \\
\hline 6 & + & H & + & - \\
\hline 7 & + & $H$ & $H$ & - \\
\hline 8 & $H$ & + & $H$ & - \\
\hline 9 & H & + & + & + \\
\hline 10 & H & + & $H$ & + \\
\hline 11 & + & H & + & - \\
\hline 12 & $H$ & + & + & + \\
\hline 13 & H & + & $H$ & - \\
\hline 14 & H & + & + & - \\
\hline 15 & + & W & + & - \\
\hline 16 & $H$ & + & + & - \\
\hline 17 & 世 & + & $H$ & + \\
\hline 18 & $H$ & + & + & + \\
\hline 19 & $H$ & + & + & - \\
\hline 20 & H & $H$ & + & + \\
\hline & & PAS & & $\begin{array}{l}70 \% \\
30 \%\end{array}$ \\
\hline
\end{tabular}

考

按

裂胞状の腺腔構造を形成寸る上皮組織成分と間質を占 めるリンパ組織成分よりなる特徵ある組織像を示寸腺 リンパ腫は1910年 Albrecht らがリンパ節内に発生した 乳頭状嫼腺腫として報告し，その後，1929 年 Warthin 
表 7 腺 リンパ腫の粘液組織化学的解析

\begin{tabular}{l|c|c|c|c|c|c|c|c|c|c|c|c|c|c|c|c|c|c|c|c}
\hline \multicolumn{1}{c}{ 症例番号 } & 1 & 2 & 3 & 4 & 5 & 6 & 7 & 8 & 9 & 10 & 11 & 12 & 13 & 14 & 15 & 16 & 17 & $\bar{t}^{\prime}$ & $\%$ \\
\hline $\begin{array}{l}\text { Surface coat } \\
\text { Intratubular }\end{array}$ & + & + & + & - & + & - & + & + & + & + & - & + & + & + & + & + & + & 14 & 82.4 \\
substance & + & + & + & + & + & + & + & + & + & + & + & + & + & + & + & + & + & 17 & 100 \\
PAS & + & + & + & + & + & + & + & + & + & + & + & + & + & + & + & + & + & 17 & 100 \\
D-PAS & + & + & + & + & + & + & + & + & + & + & + & + & + & + & + & + & + & 17 & 100 \\
$\mathrm{AB}$ & + & + & + & + & - & + & + & + & - & + & - & + & + & - & + & + & + & 13 & 76.5 \\
$\mathrm{AB}$ after SHD & - & - & - & \pm & - & - & - & - & - & - & - & \pm & - & - & - & - & - & 0 & 0 \\
$\mathrm{AB}$ after THD & - & - & - & - & - & - & \pm & - & - & - & - & - & \pm & - & - & - & - & 0 & 0 \\
$\mathrm{CI}$ & + & - & - & + & + & - & + & - & + & + & + & + & + & + & + & - & + & 12 & 70.6 \\
$\mathrm{HID}$ & - & - & - & + & - & - & - & + & - & - & - & + & + & - & - & - & - & 4 & 23.5 \\
\hline Cytoplasmic & - & - & + & - & + & + & + & - & - & + & + & - & - & - & + & + & - & 8 & 47.1 \\
substance & & & & & & & & & & & & & & & & & & & \\
PAS & - & - & + & - & + & + & + & - & - & + & + & - & - & - & + & + & - & 8 & 47.1 \\
D-PAS & + & + & + & + & + & + & + & + & + & + & + & + & + & + & + & + & + & 17 & 100 \\
$\mathrm{AB}$ & - & - & - & - & + & + & + & - & - & + & + & - & - & - & + & + & - & 7 & 41.2 \\
$\mathrm{AB}$ after SHD & - & - & - & - & - & - & - & - & - & - & - & - & - & - & - & - & - & 0 & 0 \\
$\mathrm{AB}$ after THD & - & - & \pm & - & - & - & - & - & - & - & \pm & - & - & - & - & - & - & 0 & 0 \\
$\mathrm{CI}$ & - & - & - & - & + & + & + & - & - & + & + & - & - & - & + & + & - & 7 & 41.2 \\
$\mathrm{HID}$ & - & - & - & - & + & - & - & - & - & + & + & - & - & - & - & - & - & 3 & 17.6 \\
\hline
\end{tabular}

SHD: Streptomyces-hyaluronidase digestion

THD: Testicular-hyaluronidase digestion

表 8 腺リンパ腫における粘液組成の検討

\begin{tabular}{|c|c|c|c|c|c|}
\hline \multirow{2}{*}{ 症例番号 } & \multicolumn{3}{|c|}{ AB-PAS } & \multicolumn{2}{|c|}{ HID-AB } \\
\hline & mucus & $\mathrm{AB}$ & PAS & $\mathrm{Si}$ & $\mathrm{Su}$ \\
\hline 1 & + & H & H & $H$ & + \\
\hline 2 & + & + & H & + & - \\
\hline 3 & + & + & $H$ & - & - \\
\hline 4 & + & H & $H$ & + & - \\
\hline 5 & - & - & - & - & - \\
\hline 6 & + & H & $H$ & $H$ & $H$ \\
\hline 7 & + & $H$ & W & H & H \\
\hline 8 & + & $H$ & + & + & - \\
\hline 9 & + & + & $H$ & $H$ & + \\
\hline 10 & - & - & - & - & - \\
\hline 11 & + & $H$ & + & + & - \\
\hline 12 & + & + & H & $H$ & + \\
\hline 13 & + & + & H & + & - \\
\hline 14 & + & + & $H$ & $H$ & H \\
\hline 15 & + & H & $H$ & + & + \\
\hline 16 & + & H & H & $H$ & + \\
\hline 17 & + & H & $H$ & H & + \\
\hline & $\begin{array}{l}3>\text { PAS } \\
<\text { PAS } \\
=\text { PAS }\end{array}$ & $\begin{array}{l}.05 \% \\
.17 \% \\
.00 \%\end{array}$ & $\begin{array}{l}\mathrm{Si} \\
\mathrm{Si}\end{array}$ & $\begin{array}{l}64 \\
35\end{array}$ & \\
\hline
\end{tabular}

によって乳頭状霡腺リンパ腫（papillary cystadenoma lymphomatosum) として改めて命名され，これ以後一般 的には Warthin 腫瘍と呼称されるよらになってきた。 このらちのリンパ組織成分に含まれるリンパ球は, T-cell, B-cell それぞれのマーカーを有しているものか らなっていることが知られているが，いずれが優位を示 すかはいまた統一された見解は得られていない，WHO では，1972年唾液腺腫瘍の分類を行らにあたって腺リン ハ腫の名称を採用している. 本腫湯の発生頻度は全唾液 腺腫瘍の $2 \sim 10 \%$ 前後とする報告が多く, 壮年期以後の 男性に多く発生するとされている6)

組織発生由来についてはリンパ節内に迷入残存した腺 組織に起源を求めるものや, 成熟した唾液腺組織の導管 上皮に由来し, リンパ組織の増殖も併せて生じるとする ものがあるがいまだ統一された見解は得られていない.

ところで腫瘍細胞は, その起源細胞が分化の過程でな んらかの要因によりその分化が途中で阻止され transform した形で現れてくるものとする説が現在広く認識 されている，本研究では腫瘍化した細胞においても原則 的には腫瘍化以前の細胞の形質がなんらかの形で保持さ れているであろうとする腫瘍総論的見地から正常組織の 腫瘍化に至る間の各抗原の局在分布様式の変化および, 細胞の機能表現としての産生粘液の組成の変化を組織化 学的に観察することにより腫瘍化に際しての生物学的特 
性の変化を考究することを目的とした。ささに光顕形態 学的に唾液腺組織の導管上皮に類似した腫瘍上皮成分に 着目し，これを腫瘍マーカー，分泌タンパク，細胞骨格 関連抗原の各種抗原物質の局在を酵素抗体法を用いて比 較し，また産生粘液の組成の変化を組織化学的に追求す ることによりその分化方向への位直付けを求めようとし た。

\section{1. 免疫組織化学的検索について}

本研究では1966 年, Nakane ら ${ }^{7)}$ により開発され今 日では日常的病理組織診断に頻用される酵素抗体法 $(\mathrm{ABC} \text { 法 })^{1)}$ ，を用いて，K. CEA，SC，IgA，LF，LZ の各抗原物質の局在を検索した. $\mathrm{ABC}$ 法は, Sternberger ら ${ }^{8}$ によって開発された PAP(Peroxidase-antiperocidase method) 法にくらべて感度がよく，過剩抗原時に偽陰 性 (false negative) の生じる危険がなく，操作性に優孔 ておりパラフィン切片における使用に特に適していると いわれている。

\section{Kについて}

細胞骨格 (cytoskelton) の第三構成要素として知られ る中間径線維 (intermediate filament) の一つである $\mathrm{k}$ は， $\mathrm{X}$ 線回析で $\alpha$-ヘリックス構造を示し，電顕的検索で はトノフィラメントにあたることが知られている9 . こ れは上皮細胞に多く含まれている不溶性のタンパク質群 で今日までにさまざまな方法でその抽出が試みられ，そ の性状について検討がなされてきた。そしてこれらは SDS-ポリアクリルアミドゲル電気泳動 (sodium-dodecyl sulfate polyacrylamidgel electrophoresis) 上, 分子量 40,000〜70,000 KD のポリペプチドよりなっているこ とが知られている10)

これらは分子量と等電点の違いから現在19種類のサブ ユニットが確認されており，さらに毛髧や爪，皮夙など の付属器に含まれるいわゆる hard keratin をも含める と合計 30 種類のサブュニットが見い出されている11) そ して今日これらはおのおの検索する部位によって異なっ たタイプの $\mathrm{k}$ として見出されることが明らかにされてい $ろ^{12)}$.

正常唾液腺組織における $\mathrm{k}$ の局在については内山衫 が PAP 法を用いて生検例および剖検例より得られた正 常唾液腺組織について報告しており，粘液腺，漿液腺に はいずれも発色を認めず，小葉内外の導管上皮細胞に強 い染色性を認めてはいるものの，その染色性の相違や詳 細な部位については言及していない，著者の検索では排 泄部導管上皮細胞の基底側を中心として強い染色性を示 しており, 線条部導管上皮細胞では自由縁細胞膜に中等 の陽性像を認めているが，腺房細胞にはその存在が明ら かではなかった，腫瘍組織においては，管腔を形成する 二層性の上皮細胞の基底側の細胞の胞体内に特徵的な強 い染色性を認めたが，これは正常唾液腺組織における排 泄部導管上皮細胞に見られた染色態度にきわめて類似し
たものと思われた

\section{LF について}

1939 年, S $\phi$ rensen $5^{14)}$ によって, ウシの乳汁中に 見い出され，1951年，はじめてヒト乳汁中より分離され た LF は，鉄イオン結合能によるとされる bacteriostasis を有する分子量約75,000か580,000の鉄結合性糖蛋白質 で，母乳，とくに初乳に多量に含有されていることが知

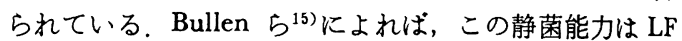
が 2 つの可逆的な鉄結 合部位を有し，鉄飽和されない aproprotein の状態で分泌されるため，分泌後，鉄イオ ンをキレートし，鉄要求性の強い微生物と競合するため と考えられているが，この外の生物学的意義については なお不明な点が多い。この LF は，血清中にはほとんど 見出されず，涙，尿，唾液，気管分泌液や好中球の二次 顆粒に多量に存在することが知られ，乳腺，唾液腺，気 管支腺などの外分泌腺細胞や白血球において産生されて いることが知られている。また T-cell 依存性に colonystimulating factor を抑制し16)，顆粒球系の抑制をなし ているということや，炎症時の貧血にも関与していると いう報告 ${ }^{17)}$ があるが，これは，生体における防御系の一 要素であることを示唆するものとして知られている.

正常唾液腺組織においては，Reitamo $5^{18)}$ Korsrud $5^{19)}$ の墏液性腺房細胞や介在部導管上皮細胞および線条 部導管上皮細胞に局在を示したといら報告や，Caselitze $ら^{20)}$ や Tourville ら ${ }^{21)}$ のよらに導管上皮細胞にはまった く局在を認めなかったといら報告がある。また綿谷ら ${ }^{22)}$ のよ5に導管上皮細胞には LF の局在を認めたが，腺房 細胞には，まったく見られなかったとしている報告もあ

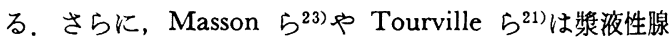
房細胞，粘液性腺房細胞ともにLF の局在を報告してい るが，実際にはこれ以降に粘液性腺房細胞に LF の局在 を見たという報告はなく，これらの報告には抗体の純度 の問題や，技術的に artifact の介在する余地が考えら れ，今日ではより詳細な検索により，新たな知見が明ら かになってきている22,24)。本研究では Korsrud ら ${ }^{19)}$, 高田ら ${ }^{25)}$ の報告と同様に，漿液性腺房細胞および介在部 導管上皮細胞に著しい局在を認めた。

腫瘍組織では検索例の40\%のものが陽性で基底側の上 皮細胞質内に局在を示寸ものもあったが，その多くは二 層性ないし多列様の上皮細胞の最内層の管腔側上皮細胞 の細胞質内全域にほぼ均一な強い局在を示した。これは 従来なされてきた報告に比べ高い陽性率であり，これま での報告はその詳細な陽性部位については述べていな い. 本研究における管腔側上皮細胞陽性所見は局所免度 機構の一翼を担うとされる IgA が同様に管腔側上皮細 胞の管腔側表層に局在したことと対比考慮すると, 感染 防御機能を有する LF が IgA と細胞膜表層で結合して bacteriostatic な能力を発揮していることの可能性を窥 わせるものであった，渡辺ら ${ }^{26)}$ は in vitro で LF と IgA 
の結合の可能性を示唆する知見を得たと報告している.

\section{SC および IgA について}

$\mathrm{SC}$ は, 分子量約 $75,500^{27)}$ ，沈降係数 4.5 の分泌性糖 タンパクであり, 消化管, 汗腺, 気管支などの諸臓器 の，腺上皮細胞で合成される。そしてこれらの上皮細胞 の basorateral plasma membrane 外に分泌され, 体液 中 (乳汁, 便, 唾液), に広く分布していることが知ら

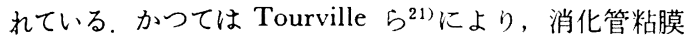
の Goblet 細胞でも合成されると報告されていたが，そ

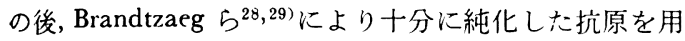
いることや，螢光抗体法による検索によりヒト Goblet 細胞内には SC の局在は証明されず，腺上皮細胞質内お よび細胞膜上にのみ $\mathrm{SC}$ を認めたと報告された。さら にその後, 加納ら ${ }^{30)}$ は䖝光抗体法を用いて commonvariable immunodeficiency 例の十二指腸粘膜の Goblet 細胞にのみ $\mathrm{SC}$ の局在を認めたとしている.

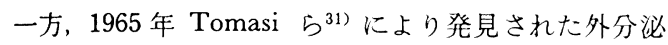
液中の IgA は, 沈降係数 11-S 分子量390,000であり,

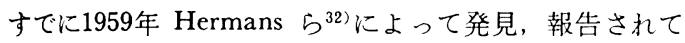
いた沈降係数 7-S を示す血清由来の IgA とは物理化学 的にも, また免疫学的にも異なるものであり, その後の 研究により ${ }^{33,34)}$ 局所の抗原刺激に応し，局所の粘膜下固 有層の形質細胞で， monomer として産生されることが 明らかにされた。この IgA は, 同様に産生される IgM とやはり局所の形質細胞で産生される分子量 $15,000 \pm$ 500 の J 鎖により重合され, おのおの dimer IgA, pentamer IgM となり，これらは上皮細胞における SCmediated transport mechanism ${ }^{28,35) を 介 し て そ れ そ ゙ れ ~}$ $(\mathrm{IgA})_{2} \cdot \mathrm{J} \cdot \mathrm{SC}$ および, $(\mathrm{IgM})_{5} \cdot \mathrm{J} ・ \mathrm{SC}$ の構造をも ち分泌型 Ig となって粘膜表面へ分泌されることが明ら かにされている ${ }^{36,37)}$ こことに前者は，局所粘膜表層での mucosal defence の役割をはたし, 局所免疫機構の一翼 を担っていると考えられている28,38,39) しかし SC その ものには免疫活性はなく，これは上皮細胞における免疫 グロブリンに対する一種の recepter carrier protein と して機能していると考えられている35) 本研究では, 正 常唾液腺組織における SC の局在を, 槳液性腺房細胞お よび, 介在部導管上皮細胞, 線条部導管上皮細胞, とり わけ，排泄部導管上皮細胞に著明に認めており，これは 従来なされてきた数多くの報告と一致する，またTourville $ら^{21)}$ は, 漿液性腺房細胞のみならす，粘液性腺房細 胞にもSC の陽性所見を得たと報告している。しかし， 彼ら以外の報告に, 粘液性腺房細胞での SC の局在を認 めたとするものが見あたらず，LF 陽性所見同様，抗体 の純度の問題, 非特異的反応などを考虙すべきであ $\eta^{22)}$, 今日的には再検討を要すると考えるのが妥当であ 万5.

IgA は SC の局在部位とよく対応し, 正常唾液腺獎 液性腺房細胞, 介在部導管上皮細胞, 腺条部導管上皮細
胞，排泄部導管上皮細胞にその局在を示し，ことに排泄 部の導管上皮細胞の管腔側上皮細胞により明らかな局在 を示していた。

$\mathrm{SC}, \mathrm{IgA}$ とも，腫湟組織においてはおのおの検索例 の73. 3\%の陽性率を示し，管腔を形成する二㬝性ないし 多列様の上皮細胞の内譤の細胞質内および，管腔側表廈 の細胞膜上に局在が見られるものが多かったが SC の中 には，基底側の上皮紏胞の basal， lateral の細胞膜上に 局在を示すものもあった。これは oncocytic な腫瘍緑胞 の分泌上皮への機能的分化を示㖫するものとした小川 $5^{40)}$ の報告を支持する結果であり, 腫瘍管腔側上皮細胞 のみならず，腫瘍基底侧上皮細胞も $\mathrm{SC}$ 合成能を有して いることを示唆するものであったＩIAにおいては，て の局在部位がおおむ水 $\mathrm{SC}$ の局在部位と合致していると ころから、これらは分泌型 IgA と考えられ， SC が IgA のリセプターとして機能していることを支持する所見と 考えられた。 そして，これらの局在は，とりわけ，管腔 側上皮細胞の管腔側表層に明らかにみられ，正常腺にお いて排泄部導管上皮細胞の管腔側に明らかな局在がみら れたことと合わせ, 腫瘍化にしてもその functional protein の局在様式は変わら寸゙, Ig.A が局所免疫機構の担 い手であることを考虑すると, 組織防衛機構についてき わめて合目的的な結果と考えられた。

\section{CEA について}

Gold と Freedman ${ }^{41,42)}$ によって, 1965年初めて胎生 $2 \sim 6$ か月のヒト胎児の腸管と, 燐酸塩食塩緩衝液によ るヒト大腸癌抽出物中より見い出された CEA は, 分子 量約 200,000 の糖タンハクであり，糖の含有量は $50 \%$ (W/W)，ほほ均一な構造を有するぺプチド鎖よりなる と考えられ, 電気泳動では band を呈する不均一な物質として認められることが知 られている。本抗原は, かつて癌特異抗原 (tumor specific antigen) であるとされたが, その後, 正常組織や, 内胚葉由来の上皮性悪性腫瘲中にもその存在が知られる よらになり ${ }^{43)}$, 癌の特異的マーカーとしての有用性は相 対的に低下した。てして現在では, 癌に特異的というよ り, 癌組織と非癌組織における量的な差異の問題と考え られるようになり 44,45) 今日的には癌の随伴抗原 (tumor associated antigen) として臨床的に広く有用性が認めら れている。ところで従来より下部消化管腫瘍では高分化 型の癌組織ほど CEA 産生能が高いとする報告が多くな されてきているが46,47)分化の低い細胞にも㕕く分布して いることが報告されておりり ${ }^{48,49)}$, 元来胎児組織に多く存 在していたことを考虑すると組織形態学的構造とは別に CEA 産生細胞は胎韭組織への逆分化の傾向を有する細 胞と考えることができる。

この CEA の正常唾液腺組織における局在は, 腺房細 胞に認めたとする Itoiz ら $5^{50)}$, 綿谷ら ${ }^{22)}$. McDicken $ら^{51)}$, Caselitz $5^{52)}$ の報告があり, このうち Itoiz ら 
は，導管上皮細胞には局在を認めなかったと述べている のに対し，綿谷ら ${ }^{22)}$ は，導管上皮細胞にも局在を認めた としている。本研究では，その染色性に若干の差異はあ るものの，いずれの導管上皮細胞にも抗原の局在が認め られた。しかし，CEA それ自体はすでに種々の細胞に 見出されており，CEA 関連抗原の存在も含め考える と, その差異は質的なものではなく，量的なものと考え るのが妥当であり，さらに純度の高い抗体を作製して検 索していく必要があると思われる.

腫瘍組織における CEA の局在は，検索例の66.6\%に みられ，二層性を示す管腔側上皮細胞では basal， lateral の細胞膜および自由縁細胞膜にみられる部分, 多列様の 管腔側上皮細胞では，細胞質内にびまん性にみられる部 分とがあった。細胞質内での染色性は，細胞膜上におけ るそれに比べて劣っていたが，これは CEA が細胞質内 で合成されることを示唆する所見と考えられた。

\section{LZ について}

ライソゾーム酵素の一つで菌壁のムコ多糖体を溶解す

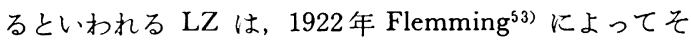
の存在が報告された分子量約 14,000 の抗菌性加水分解酵 素で，その溶菌作用は，N-アセチルグルコサミンと Nアセチルムラミン酸間の $\beta$-(1.4) 結合の切断によること が知られている。

正常唾液腺組織における LZ の局在は高田ら ${ }^{25)}$, Korsrud 5 ${ }^{19)}$ ，のように漿液性腺房細胞および介在部導 管上皮細胞にその局在を認めたといら報告や，Klockars $5^{54)}$ のよ 5 腺房細胞にはその局在を認めず小葉内導管 上皮細胞にのみ局在を認めたとするもの，また Reitamo ら ${ }^{55)}$ のよらに小唾液腺組織においては粘液性腺房細胞に もその局在を認めたとするなど種々の報告がある．本研 究では介在部導管上皮細胞および漿液性腺房細胞に強い 染色性を認め, 線条部導管上皮細胞にも弱い染色性を示 したが，排泄部導管上皮細胞には明らかな局在は見られ す，おおむね高田 $5^{25)}$ ，Korsrud $5^{19)}$ の報告と一致し た。しかし腫瘍組織において LZ の局在を示す報告は見 られず，今回の検索例においても明らかな局在を示すも のは得られなかった。このことは正常唾液腺細胞の腫瘍 化に際し LZ がなんらかの重要な関りを有しているこ とを示唆する所見と考えられた。

\section{7. 粘液組織化学的検索について}

今日，生体内粘液物質の総称としていわれるいわゆる ムチンは，多糖類とタンパク質との複合糖質からなるこ とが明らかにされており，この生体内で合成される複合 糖質は, 重要な生理学的活性能を有することが知られて いる。これらのいわゆる粘液物質 (mucosubstance) は 糖鎖部分の結合様式により，グリコプロティンとプロテ オグリカンに大別されており，グリコプロティンはさら に血清型とムチン型とに別れるが，いわゆる上皮性粘滩 は寸べてムチン型糖蛋白質であることが知られている。
このムチン型糖蛋白質は粘液組織化学的に Spicer ${ }^{56)} に$ より,酸性粘液と中性粘液に大別されており,さらに酸性 粘液は硫酸基 (sulfate ester) の有無によって surfomucin と sialomucin に分類されているが，なかにはおのおの のエステルを共有するものの存在を示唆する報告もなさ れている57,58).

近年, 複合糖質の組織化学の進歩により腫湯化に伴5 糖質の変化が組織レベルで詳細に検討されるよ5になり 肺, 胃, 大腸など, 腺系腫瘍の発生母地となる諸臟器に おいて腫瘍化に伴って変性するムチンの組成の解析を試 みる研究, 報告が数多くなされるよらになってきてい る。この複合糖質の一つであり，上皮細胞の外分泌物で ある粘液物質 (mucosubstance) の産生能を有する正常 唾液腺組織が腫瘍化に伴い, 細胞の機能表現としての産 生粘夜の組成にいかなる変化を示すか粘液組織化学的に 検索した。 また各種抗原物質の局在との関連はどうか検 討した。

本研究においては正常唾液腺組織の腺房細胞はジアス ターゼ抵抗性を示す豊富な PAS 反応陽性の粘液物質を 有していた，この PAS 反応は過ヨウ素酸に酸化剂を用 い,これに Shiff 試薬を反応させたものであり，この反 応により natural mucin は特異的に赤く染まる， surfomucin は pH 2.5 Alucian-Blue 染色で, 青く染まり，

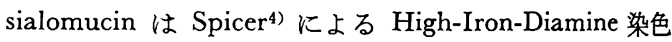
で特異的に黒褐色に染色されることが知られている.

また各導管上皮細胞にも少量ながら mucin の存在を らかがわせる surface coat, cytoplasmic substance, intratubular substance を有しておりこれは各導管系 の中でも腺房細胞に近位の部位すなわち, 介在部に多く 見られ，腺房細胞より遠位の排泄部ではきわめて少なく なっていた。これは一定の分化の過程で形態のみならず 機能においても一定の順序が存在するとともに粘液産生 能といら functional piece は保持され続けていることを 示㖫するものと考えられる。 また腺リンパ腫の上皮細胞 成分では明らかな含有粘液の低下がみられた。このこと は腫瘍化に伴って腺組織の粘液産生が減少することを示 唆し，従来よりいわれてきた導管上皮由来を支持しらる 染色態度と考えられた。 そして産生された粘液の性状は 正常唾液腺組織では PAS 反応陽性, ジアスターゼ耐 性, AB 陽性の酸性ムチンを有するものが20例中16例, 80\%と優位であったのに対し，腺リンパ腫では酸性ムチ ン優位を示すものは17例中 8 例, $47.05 \%$ でありグリコ ーゲンを主体とする PAS 反応物質優位を示すものは 17 例中 7 例, $41.17 \%, \mathrm{AB}$ 陽性, PAS 陽性とも, 同程度 のもの17例中 2 例, $11.76 \%$ であった。 これは腫瘍化に 伴い酸性粘液の産生は著しく減少する傾向を示唆するも のと考えられた。 また酸性粘液の組成は正常唾液腺組織 では sialomucin が20例中14例，70\% と優位を示し，腺 リンパ腫においても20例中 11 例, $64.70 \%$ と優位を示し 
ており酸性粘液は腫瘍化に伴ってその組成に大きな変化 を示さないことが示唆された。

さらに腫瘍組織における上皮細胞成分の中の酸性么二 多糖群の同定を醳素消化試験を行らことにより試みた が, 本研究では, いずれの腫旿組織においてもヒアルロ

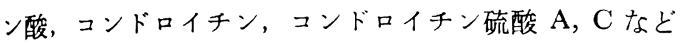
の明らかな所在は籍われず，本腫瘍形成における筋上皮 性細胞関与に否定的な所見であった。 また対照として用 いた正常唾液腺組織においてはコンドロイチン，コンド ロイチン硫酸 A，C の消化を示㖫する染色性の低下がわ ずかに見られたが，多くは消化されておらずこの他の GAG の存在を示唆していた。 またヒアルロン酸消化試 験では明らかな消化所見は得られなかったがこれはムこ 多糖類産生に関与するとされる筋上皮性細胞が，唾液腺 組織の主要な構成成分であることを考虑すると興味ある 所見と考えられた．しかし通常の10〜20\%ホルマリン固 定では組織中のヒアルロン酸の溶出が考虑されねばなら ず,ささらに詳細な検索を要するものと考える。また各抗 原の局在と産生粘液を検討すると腫瘍管腔内の粘液物質 はその染色部位の合致を認めたが胞体内粘液物質および 細胞膜上ではその染色性に重複を認めない傾向を示し た。このことにより, 粘液産生能を有する細胞は粘液非 産生性細胞にくらべて機能的に分化度の高い状態の細胞 と考えるならば，今回用いた各抗体はいずれも腺りンパ 腫の比較的機能的分化度の低い状態の細胞に多く局在す る傾向にあるのではないかと考えられた。

\section{結}

語

腺リンパ腫およびヒト正常唾液腺組織37例について, 免疫組織化学的に Carcinoembryonic antigen, Secretory component, IgA, Keratin, Lactoferrin, Lysozyme の各 局在を検討し，さらに粘液組織化学的に中性粘液，酸性 粘液, sialomucin, sulfomucin の各分布の検索と上皮細 胞に含まれるムコ多糖群の同定を試み，以下の知見を得 た.

\section{1. 免疫組織化学的検索について}

IgA, Lactoferrin, Secretory component の正常唾液 腺組織に拈ける各局在は acinus unit の防御を示唆し, 腫湯組織においては, SC-IgA，IgA-LF の各結合を䇲わ せ, SC-mediated transport mechanisum と local immune system の存在を裏付ける組織防御機構に合目的 的な所見であった。 また腫瘍組織における Keratinの局 在は排泄部導管上皮細胞に類似した上皮基底側細胞に濃 染する特徴的な像を示し, 本腫瘍の排泄部導管上皮由来 を強く窺わせる染色態度であった。一方 Lysozyme が 腫癔化に伴い明らかな陽性率の低下を示したことは Lysozyme が腫瘍化に際し，なんらかの関わりを有する ことを窥わせるものであった。

\section{2. 粘液組織化学的検索について}

正常唾液腺組織における産生粘液は酸性粘液優位であ り, 腫瘍組織では酸性粘液の産生は減少したが酸性粘液 の組成は正常唾液腺組織, 腫痬組織ともに sialomucin 優位であった。正常唾液腺組織では酵素消化処理を行う ことにより glycosaminoglycan の存在が窥われたが腫瘍 組織では明らかな glycosaminoglycan の存在は窥われ ず，本腫瘍形成に扣ける筋上皮細胞関与が否定的に支持 された。腫瘍組織に㧍ける各抗体と粘液の重染色では, いずれの抗体においてもその局在部位と粘液産生細胞は 解離する傾向が見られ, 粘液産生能を有する細胞を機能 的に比較的分化度の高い状態の細胞と考えると Carcinoembryonic antigen, Keratin, Secretory component, IgA, Lactoferrin, Lysozyme の各抗体はいずれも腺リン 八腫の比較的分化度の低い状態の細胞に局在する可能性 が細胞機能の面から窥われた。ことに Carcinoembryonic antigen においては元来胎児組織に多く存在してい たことを考虑するとその局在は組織形態学的構造とは別 に細胞の胎児性組織への逆分化の指標となりらることが 示唆された。

稿を終えるにあたり本研究課題を与えられ，終始ご愁 篤なるご指尊, こ校閲を晹わりました恩師内田安信主任 教授に深謝致します。また本研究を直接こ指導頂きまし た本学病理学教室佳々弘教授に深謝致します。材料の検 索を扣許しくださいました本学病院病院病理部長海老原 善郎助教授, 終始かわら煌こ助言, ご教示を頂きました 本学口腔外科学教室北島晴比古諩師に併せて深謝致しま 寸.

本論文の要旨の一部は第 71 回日本病理学会総会（東 京), 第 11 回日本頭頸部腫痬学会総会 (東京) にて発表 した。

\section{引 用 文 献}

1) Hsu, S.M., Reine, L., et al: Use of AvidinBiotin-Peroxidase Complex ( $\mathrm{ABC}$ ) in immunoperoxdase techniques. A comparison between $\mathrm{ABC}$ and unlabeled antibody (PAP) procedures. J Histochem Cytochem 29: 5775801981.

2) 日本組織細胞化学会編：組織細胞化学 1981 . 第 1 版, 学際企画, 東京, 1981，175-194頁.

3) 勝山 努, 本田孝行: 粘液組織化学 (1) 染色 法の概要。医学のあゆみ 127：中付 1983.

4) Spicer, S.S.: Diamine method for differentiating mucosubstances histochemically. J Histochem 13: 211-234 1965.

5) 日本組織細胞化学会編: 組織細胞化学1984. 第 1 版, 学際企画, 東京, 1984, 19-32面.

6) 石川梧朗監修: 口腔病理学. 改訂版, 永末書 
店, 京都, 1986, 731-735頁.

7) Nakane, P.K. and Piece, C. G.: Enzyme-labeled antibodies: preparation and application for localization of antigens. J Histochem $\mathrm{Cy}-$ tochem 14: 929-931 1966.

8) Sternberger, L.A., Hardy, P.H., et al.: The unlabeled antibody enzyme method of immunohistochemistry. Preparation and properties of soluble antigen antibody complex (horseradish peroxidase-antihorseradish peroxdase) and its use in identification of spirochetes. J Histochem Cytochem 18: 315-333 1970.

9) Matoltsy, A.G.: Desmosomes, filaments, and keratohyaline granules: their role in the stabilization and keratinization of the epdermis. J Invest Dermatol 65: 127-142 1975.

10) Laemmli, U.K.: Cleavage of structual proteins during the assembly of the head of bacteriophage T 4. Nature 227: 680-685 1970.

11）森永正次郎, 中島 孝, 他: 中間径フィラメン 卜。病理と臨床 5：384-394 1987.

12) Fuchs, E. and Green, H.: The expression of keratin genes in epidermis and cultured epidermal cells. Cell 15: 887-897 1978.

13) 内山元泰：唾液腺の免疫組織化学的研究 B VI ケラチン蛋白の組織内局在の検討. 日大歯学 55: 978-986 1981.

14) S $\phi$ rensen, M. and S $\phi$ rensen, S.P.L.: The proteins in whey; C.R. Lab. Carlsberg ser Chim 22: 55-99 1939.

15) Bullen, J.J., Rogers, H. J., et al.: Ironbinding proteins in milk and resistance to escherichia coli infection in infants. $\mathrm{Br} \mathrm{Med}$ J 8: 69-75 1972.

16) Bagby, G.C., Vasiliki, Jr., et al.: Interaction of lactoferrin, monocytes, and $\mathrm{T}$ lymphocyte subsets in the regulation of steady-state granulopoiesis in vitro. $\mathrm{J}$ Clin Invest 68: 56-63 1981.

17) Van Snick, J.L., Masson, P.L., et al.: The involvement of lactoferrin in the hyposideremia of acute inflammation. J Exp Med 140: 1068-1084 1974.

18) Reitamo, S., Konttinen, Y.T., et al.: Distribution of lactoferrin in human salivary glands. Histochemistry 66: 285-291 1980.

19) Korsrud, F.R. and Brandtzaeg, P.: Charactrization of epitherial elements in human major salivary glands by functional makers. J Histochem Cytochem 30: 657-666 1982.

20) Caselitz, J., Jaup, T., et al.: Lactoferrin and lysozyme in carcinomas of the parotid gland. Virchows Arch 394: 61-73 1981.

21) Tourville, D.R., Alder, R.H., et al.: The human secretory immunoglobulin system: immunohistological localization of $\gamma \mathrm{A}$, secretory "piece" and lactoferrin in normal human tissues. J Exp Med 129: 411-429 1969.

22）綿谷和也，白砂兼光，他：七卜顎下唾夜腺に打 ける種々の喠液蛋白の分布. 日口外誌 $31: 222$ 2291985.

23) Masson, P.L., Hermans, J.F., et al.: An iron binding protein common to many external secretions. Clin Chem Acta 14: 735-739 1966.

24）浜川裕之, 土井正，他：七卜唾液腺腫瘍の免 疫組織化学的研究. 日口外誌 $32: 1109-1120$ 1986.

25）高田隆, 小川郁子, 他: 唾液腺腫瘍の免疫組 織化学的研究. 䁖基礎誌 26: 1190-1199 1984.

26）渡辺敏蛼, 名倉 宏, 他 : ヒトラクトフェリン とヒト IgA との結合。医学のあゆみ 125:2562581983.

27) Brandtzaeg, P.: Mucosal and glandual distribution of immunoglobulin components: Differential localization of free and bound SC in secretory epitherial cells. J Immunol 112: 1553-1559 1974.

28) Brandtzaeg, P.: Structure, synthesis and external transfer of mucosal immunoglobulins. Ann Immunol 124: 417-438 1873.

29) Brandtzaeg, P.: Mucosal and glandular distribution of immunoglobulin components. Immunohistochemistry with a cold ethanol fixation technique. Immunology 26: 110111141974.

30）加納 正, 内野浩人, 他：腸管粘膜における Secretory component 産生細胞に関する検討. 日消病会誌 76: 1271-1276 1979 .

31) Tomasi, T.B., Tan, E.M., et al.: Characteristics of an immune system common to certain external sections. J Exp Med 121: 101-125 1964.

32) Hermans, J.F., Hermans, M. T.H., et al.: Isolation and description of a few properties of the $-2 \mathrm{~A}$ globulin of human serum. Clin Chem Acta 4: 96-102 1959.

33) Hermans, J.F.: Immunoglobulin formation and function in different tissues. Curr Top Microbiol 45: 142-146 1968.

34) Brandtzaeg, P., Fjellanger, I., et al.: Human secretory immunoglobulins. I. salivary secretions from individuals with normal or low levels of serum immunoglobulins. Scand J Haematol suppl 12: 1-83 1970.

36）谷内 昭, 前田修一, 他：ヒトの分泌型免疫グ ロブリン系の分布と機能. 日本臨床 35: 163716441977.

37）細田四郎, 馬場忠雄, 他：腸管の Secretory IgA dimer の産生機序とその異常. 日本臨休 
35: 1627-1637 1977.

38) Tomasi, T.B. Jr. and Bienstock, J.: Secretory immunoglobulin. Ady Immunol 9: 1-96 1968.

39) Tomasi, T.B. Jr.: Secretory immunoglobulins. New Eng J Med 287: 500-506 1972.

40) 小川郁子, 高田隆, 他: 㕰液腺腫濐の免疫組 織化学的研究. 读基礎誌 26：1200-1209 1984.

41) Gold, P. and Freedman, S.O.: Demonstration of tumor-specific antigen in human colonic carcinomata by immunological tolerance and absorption techniques. J Exp Med 121: 4394621965.

42) Gold, P. and Freedman, S.O.. Specific carcinoembryonic antigens of the human degestive system. J Exp Med 122: 467-481 1965.

43) Martin, F. and Martin, M.S.: Demonstration of antigens related to colonic cancer in the human degestive system. Int $\mathrm{J}$ Cancer 6: 352-360 1970.

44) Huitric, E., Laumonier, R., et al.: An optical and ultrastructural study of the localization of carcinoembryonic antigen (CEA) in normal and cancerous human rectocolonic mucosa. Lab Invest 34: 97-107 1976.

45) Isaacson, P. and Judo, M.A.: Carcinoembryonic antigen (CEA) in the normal human small intestine: a light and electron microscopic study. Gut 18: 786-791 1977.

46) 和久本博: Carcinoembryonic antigen (CEA) の免疫組織化学的研究. 阪大医誌 $27: 17-26$ 1975.

47) 小泉欣也, 安富 徽: 胃粘膜組織内の CEA の 局在々濃度の研究。癌の臨 26: 36-44 1980.

48）鈴木光明, 大和田倫孝, 他：子宮頸部および体 部腺癌の組織, 細胞レベルでの Carcinoembryonic Antigen 産生機能。日産婦誌 37：8979021985.
49) Cohen, C., Shulman G., et al.: Endocervical and endometrial adenocarcinoma. Am J Surg Pathol 6: 151-157 1982.

50) Itoiz, M.E., Lanfranchi, H.E., et al.: Immunocytochemical defection of carcinoembryonic antigen in salivary gland tumors. Int Oral Surg 12: 340-343 1983.

51) McDicken, I.W. and Scott, J.: The presence and distribution of carcinoembry in tumors of human minor salivary glands. J Oral Pathol 10: 296-303 1981.

52) Caselitz, J., Seifert, G., et al.: Presence of carcinoembryonic antigen (CFA) in the normal and inflamed human parotid gland. An immunohistochemical study of 31 cases. J Cancer Res 100: 205-211 1981.

53) Fleming, A.: On a remarkable bacteriolytic element found in tissues and secretions. Proct R Sos 93: 306-317 1922.

54) Klokars, M. and Reitmano, S.: Tissue distribution of lysozyme in man. J Histochem Cytochem 23: 932-940 1975.

55) Reitamo, S., Klockers, M., et al.: Immunohistochemical identification of lysozyme in the minor salivary glands of man. Arch Oral Biol 22: 515-519 1977.

56) Spicer, R.R.: Suggestion for a histochemical terminology of carbohydrate rich tissue component. J Histochem Cytochem 13: 599-603 1965.

57) Pearse, A.G.E. Histochemistry: Theoretical and Applied. Little Brown and Co, Boston Mass, 1961.

58) Spicer, S.S. and Duvenci, J.: Histochemical characteristics of mucopolysacchrides in salivary and exorbital lacrimal glands. Anat Rec 149: 333-358 1964. 